\title{
Interaction of human chagasic IgG with human colon muscarinic acetylcholine receptor: molecular and functional evidence
}

\author{
L Sterin-Borda, J C Goin, C R Bilder, G Iantorno, A C Hernando, E Borda
}

\begin{abstract}
Background and aims-Gastrointestinal disorders is one of the clinical manifestations of chronic Chagas' disease. The pathogenesis seems to be associated with autonomic dysfunction. Here, we consider the muscarinic cholinoceptor mediated alteration in distal colon function in chagasic megacolon.

Patients-Patients were divided into four groups: group I, chronic chagasic patients with megacolon; group II, chronic chagasic patients without megacolon; group III, nonchagasic patients with megacolon; and group IV, normal healthy volunteers (control). Methods-Binding assay and immunoblot of cholinoceptors from human and rat colon and enzyme immunoassay (ELISA) using a synthetic $24 \mathrm{mer}$ peptide corresponding to the second extracellular loop of human $M_{2}$ muscarinic acetylcholine receptors (mAChR) were used to detect the presence of serum antibodies. The effect of antibodies on basal tone and 3',5'cyclic monophosphate (cAMP) production of human and rat distal colon strips were also tested.
\end{abstract}

Results-Group I but not the other groups had circulating antibodies capable of interacting with human colon activating $\mathbf{M}_{2}$ mAChR, as they competed with binding of specific radioligand to $\mathrm{mAChR}$ and interacted with the second extracellular loop of human $\mathbf{M}_{2}$ mAChR. Moreover, affinity purified anti-M $M_{2}$ peptide IgG from group $I$, in common with monoclonal antihuman $M_{2}$ mAChR, recognised bands with a molecular weight corresponding to colon mAChR. This antibody also displayed an agonist-like activity, increasing basal tone and decreasing cAMP accumulation. Both effects were blunted by AF-DX 116 and neutralised by the synthetic peptide.

Conclusions-In chagasic patients with megacolon there are antibodies that can recognise and activate $M_{2} \mathrm{mAChR}$. The implications of these autoantibodies in the pathogenesis of chagasic megacolon is discussed.

(Gut 2001;49:699-705)

Keywords: chagasic megacolon; acetylcholine receptor; antibodies; colon contractility

Chagas' disease is a parasitic disease that represents one of the most serious public health problems in South America. The clinical picture of this disease is dominated by cardiac and digestive disorders.
The digestive manifestations mainly involve megaoesophagus and megacolon. ${ }^{1}$ The abnormalities of the autonomic enteric nervous system seem to be an essential element in the pathogenesis of chagasic megavisceras. These abnormalities include degeneration and reduction in the number of myenteric plexus that coordinate the motor activity of different segments from the oesophagus to the rectum. ${ }^{2}$ These lesions occur throughout the digestive tract but the oesophagus and distal portion of the colon are the parts most affected because of the physiology of these segments. ${ }^{3}$ Furthermore, both regions have a sphincter at their end that must relax by a reflex mechanism. Chagasic megacolon has been described as a dysautonomic related disorder in which excitatory neural influences on colon motility seem to be unopposed by the impaired inhibitory neural influences that govern smooth muscle relaxation. $^{4-6}$

In fact, abnormalities of the distal colon $^{7-9}$ as well as impairment of the relaxation response of the internal sphincter to rectal distension have been described in chagasic patients. ${ }^{6-8}$ Moreover, the motor responsiveness of the distal colon to cholinergic agents ${ }^{7}$ and to several pharmacological and physiological stimuli is altered. This defect may play a pathophysiological role in colonic disease. ${ }^{9} 10$

There is evidence that the enteric nervous system exerts local control of gastrointestinal function by multiple mechanisms. Excitatory motor neurones connected to the excitatory parasympathetic pathways is one of the determinants of colonic motility. These motor neurones release acetylcholine and it acts postjunctionally between motor neurones and muscarinic acetylcholine intestinal receptors (mAChRs) of muscle. ${ }^{11-13}$ The coexistence of more than one mAChR subtype with different contractile roles has been demonstrated in the colon..$^{14}$

Most studies on cholinergic response of chagasic megacolon have focused on the integrity of preganglionic and postganglionic innervation without further consideration of eventual alterations in the effector muscarinic response. ${ }^{15}$ Muscarinic cholinoceptor mediated modulation of colonic function in chagasic megacolon remains to be clarified.

We showed previously the presence of serum autoantibodies against $\mathrm{mAChR}$ in patients with chronic Chagas' disease. ${ }^{16}{ }^{17}$ These antibodies

Abbreviations used in this paper: $\mathrm{mAChR}$, muscarinic acetylcholine receptor; $\mathrm{PGE}_{1}$, prostaglandin $\mathrm{E}_{1}$; cAMP, 3',5'-cyclic monophosphate; NMS, $\mathrm{N}$-methylscopolamine; KRB, Krebs-Ringer bicarbonate. 
displayed an "agonist-like" activity modifying intracellular events associated with $\mathrm{M}_{2} \mathrm{mAChR}$ activation. ${ }^{17}$ These anti- $\mathrm{M}_{2} \mathrm{mAChR}$ antibodies were associated with the presence of cardiac dysautonomia and/or achalasia in patients with chronic Chagas' disease. ${ }^{16-18}$

The aim of this study was to investigate the presence of anti- $\mathrm{M}_{2} \mathrm{mAChR}$ antibodies in patients with chronic Chagas' disease and megacolon. We have confirmed that such antibodies arise as a result of the chagasic state and that they interact with human colon activating $\mathrm{M}_{2} \mathrm{mAChR}$, indicating a role for the second extracellular loop of human $\mathrm{M}_{2} \mathrm{mAChR}$ as the main target for human autoantibody mediated biological effects.

\section{Methods}

PATIENTS

All patients $(n=55)$ aged between 31 and 75 years were living in metropolitan Buenos Aires at the time of the study, although all chagasic patients had previously resided in areas endemic for Trypanosoma cruzi. A diagnosis of Chagas' disease was made on the basis of three standard serological reactions against $T$ cruzi: passive haemagglutination, indirect immunofluorescense, and enzyme immunoassay. Subjects were divided into three groups: group I consisted of 15 chronic chagasic patients with megacolon (eight men and seven women); group II comprised 17 chronic chagasic patients without megacolon (10 men and seven women), and group III consisted of three nonchagasic patients with megacolon (two men and one woman; mean age 59.4 (4.8) years). Group IV (normal controls) included 20 healthy volunteers (10 men and 10 women). Patients in groups I and III had clinical and radiological findings characteristic of megacolon. Barium enema showed sigmoid dilatation and/or elongation in all patients. Abnormalities of basal motility of the distal colon as well as impairment of the relaxation response of the sphincter on rectal distension were also observed in megacolon patients. Conversely, patients in group II showed no evidence of bowel alteration. Regardless of the presence of megacolon in patients in groups I and III, none of the subjects had evidence of cardiovascular, neurological, metabolic, and/or systemic disease. Patients with acute or other chronic disorders were not included in the study. None of the patients was taking medications during and/or 72 hours before blood samples were obtained and clinical studies performed. Each subject gave fully informed consent under a protocol approved by the Gastroenterology Hospital Research Committee.

DRUGS

Atropine, carbachol, prostaglandin $\mathrm{E}_{1}\left(\mathrm{PGE}_{1}\right)$, and 3-isobutyl-1-methylxanthine were purchased from Sigma Chemical Company (St Louis, Missouri, USA). [[2-[(diethylamino) methyl]-1piperidinyl] acetyl]-5,11-dihydro-6H-pyrido[2,3b] $[1,4]$ benzodiazepine-6-one (AF-DX 116) was kindly provided by Boehringer Ingelheim Pharmaceuticals Inc. (Ridgefield, Connecticut, USA). $\left[{ }^{3} \mathrm{H}\right]$ adenosine 3 ',5'-cyclic monophosphate $\left(\left[{ }^{3} \mathrm{H}\right]\right.$ cAMP $\left.30.5 \quad \mathrm{Ci} / \mathrm{mmol}\right)$ and $\left[{ }^{3} \mathrm{H}\right]$ $N$-methylscopolamine $\left(\left[{ }^{3} \mathrm{H}\right]\right.$ NMS $80.4 \mathrm{Ci} /$ $\mathrm{mmol}$ ) were purchased from New England Nuclear (Boston, Massachusetts, USA).

TISSUE SAMPLES

Human resection specimens were obtained from the distal colon from patients aged 31-65 years (three men and two women) undergoing partial colectomy for chagasic megacolon. A healthy section of the colon was carefully separated from the pathological tissue under the stereomicroscope at room temperature. Male Wistar rats (200-250 g) were decapitated and bled; strips of distal colon were then taken. Both human and rat distal colon samples were washed with ice cold phosphate buffered saline and subjected to further dissection. The mucosal, submucosal, and serosal layers were carefully removed, leaving the smooth muscle layer. ${ }^{19}$ Human and rat tissue homogenates for ligand binding assay and western blot analysis were obtained as previously described. ${ }^{16}$

\section{PURIFICATION OF HUMAN IgG}

The IgG fraction from chagasic patients with megacolon or from normal subjects (control) was isolated by chromatography on diethylaminoethyl-cellulose, as previously described. ${ }^{17}$ IgG was concentrated by ultrafiltration to about $10-12 \mathrm{mg} / \mathrm{ml}$. The degree of IgG purification was tested by sodium dodecyl sulphate-polyacrylamide gel electrophoresis and its concentrations were determined by radial immunodiffusion assay.

\section{COMPETITION BINDING STUDIES}

Membranes from rat or human distal colon smooth muscle $(2.5-3.0 \mathrm{mg} / \mathrm{ml})$ were preincubated with different concentrations of the IgG fraction from either chagasic patients with megacolon or normal subjects for one hour at $30^{\circ} \mathrm{C}$ in buffer $\mathrm{A}$. The membranes were then incubated with $0.6 \mathrm{mM}\left[{ }^{3} \mathrm{H}\right] \mathrm{NMS}$ for two hours at $25^{\circ} \mathrm{C}$ in buffer A (final volume 0.5 $\mathrm{ml}$ ). The reaction was stopped with ice cold buffer A and filtered through Whatman glass fibre filters $(\mathrm{GF} / \mathrm{c})$ under vacuum. Filters were washed three times with $4 \mathrm{ml}$ of buffer $\mathrm{A}$ and counted in an $8 \mathrm{ml}$ scintillation cocktail with $0.56 \%$ efficiency. Non-specific binding was determined in the presence of $1 \times 10^{-6} \mathrm{M}$ atropine and did not exceeded $10 \%$.

\section{PEPTIDE}

A 24 mer peptide (V-R-T-V-E-D-G-E-C-Y-I-QF-F-S-N-A-A-V-T-F-G-T-A) and a 25mer peptide (K-R-T-V-P-D-N-Q-C-F-I-Q-F-L-S-N-PA-V-T-F-G-T-A-I) corresponding to the sequences of the second extracellular loop of human $\mathrm{M}_{2}$ and $\mathrm{M}_{3} \mathrm{mAChRs}{ }^{16}$ were synthesised (model 413; Applied Biosystem, Foster City, California, USA). The peptide was desalted, purified by high pressure liquid chromatography, and subjected to amino terminal sequence analysis by automatic Edman degradation with an Applied Biosystem (model 470 A) Sequencer. 

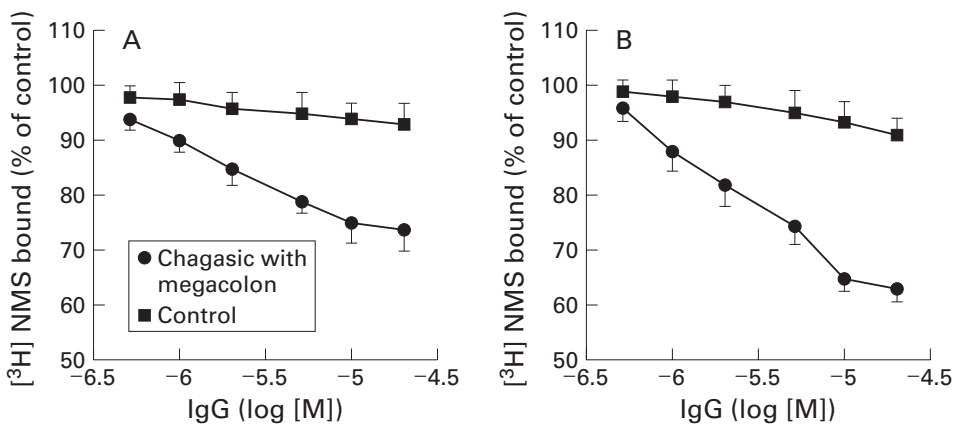

Figure 1 Concentration dependent inhibition of [ $\left.{ }^{3} \mathrm{H}\right] \mathrm{N}$-methylscopolamine (NMS) binding on colonic smooth muscle membranes. Rat $(A)$ and human $(B)$ colon smooth muscle homogenates were incubated with serum IgG from either chagasic patients with megacolon or normal individuals in the presence of $[\mathrm{H} H] \mathrm{NMS}$. Control binding of $100 \%$ refers to the binding of the muscarinic radioligand to membranes treated with no IgG. Data are mean (SEM) of triplicate determinations of five IgGs from different chagasic or normal subjects.

PURIFICATION OF ANTIPEPTIDE ANTIBODIES

The IgG fractions from five chagasic patients with megacolon with the highest serum anti- $\mathrm{M}_{2} \mathrm{mAChR}$ titres were independently subjected to affinity chromatography on the synthesised peptide covalently linked to AffiGel 15 gel (Bio Rad, Richmond, California, USA) and purified as previously described. ${ }^{18}$ The IgG concentration of antipeptide antibodies was determined by radial immunodiffusion assay, and immunological reactivity against the muscarinic receptor peptide was evaluated by enzyme immunoassay.

\section{ENZYME IMMUNOASSAY}

Peptide solution $(50 \mu \mathrm{l}$ of $20 \mu \mathrm{g} / \mathrm{ml})$ in $0.1 \mathrm{M}$ $\mathrm{Na}_{2} \mathrm{CO}_{3}$ buffer, $\mathrm{pH}$ 9.6, was used to coat microtitre plates (NUNC, Kastrup, Denmark) at $4^{\circ} \mathrm{C}$ overnight, as previously described. ${ }^{18}$ Briefly, after blocking the wells, diluted sera or IgG from chagasic or control patients were added in triplicate and allowed to react with the peptide for two hours at $37^{\circ} \mathrm{C}$. After thoroughly washing, $100 \mu \mathrm{l}$ of 1:6000 biotinylated goat antihuman IgG antibodies (Sigma) were added and incubated for one hour at $37^{\circ} \mathrm{C}$. Then, a 1:6000 dilution of ExtrAvidin/alkaline phosphatase (Sigma) was added. After extensive washings, p-nitrophenylphosphate $(1 \mathrm{mg} /$ $\mathrm{ml}$ ) was added as substrate and the reaction was stopped after 30 minutes. The plates were read at $405 \mathrm{~nm}$.

Table 1 Effect of chagasic antibodies on [3] $\mathrm{H}$-methylscopolamine (NMS) binding on rat and human distal colon

\begin{tabular}{|c|c|c|c|c|}
\hline & \multicolumn{4}{|c|}{$\left[{ }^{\beta} H\right]$ NMS binding } \\
\hline & \multicolumn{2}{|l|}{ Rat } & \multicolumn{2}{|l|}{ Human } \\
\hline & $B \max$ & $K d$ & $B \max$ & $K d$ \\
\hline None (control) & $20.3(1.2)$ & $1.43(0.22)$ & $32.0(2.3)$ & $1.36(0.19)$ \\
\hline Group I & $14.8(0.9)^{\star}$ & $1.45(0.28)$ & $20.6(1.8)^{\star}$ & $1.40(0.20)$ \\
\hline Group II & $21.4(1.4)$ & $1.40(0.24)$ & $33.2(1.9)$ & $1.38(0.20)$ \\
\hline Group III & $22.5(1.4)$ & $1.44(0.27)$ & $34.3(3.0)$ & $1.41(0.18)$ \\
\hline Group IV & $21.2(1.3)$ & $1.38(0.21)$ & $31.8(2.6)$ & $1.38(0.17)$ \\
\hline
\end{tabular}

Colonic smooth muscle homogenates $\left(0.9 \mathrm{mg}\right.$ ) were or were not incubated with $1 \times 10^{-5} \mathrm{M} \mathrm{IgG}$ from chagasic patients with megacolon or $\mathrm{IgG}$ from normal subjects in the presence of increasing concentrations of $\left[{ }^{3} \mathrm{H}\right]$ NMS. The number of binding sites (Bmax) expressed as $\mathrm{fmol} / \mathrm{mg}$ protein and the equilibrium dissociation constant $(\mathrm{Kd})$ expressed as $\mathrm{nM}$ were calculated from linear regression analysis. Mean (SEM) of triplicate determinations of five IgGs from different groups. Group I, chagasic patients with megacolon; group II, chagasic patients without megacolon; group III, non-chagasic patients with megacolon; group IV, normal subjects.

* Significantly different from normal IgG, $\mathrm{p}<0.001$.
WESTERN BLOT

Membranes from rat or human distal colon smooth muscle were subjected to electrophoresis on $8.5 \%$ sodium dodecyl sulphatepolyacrylamide gels. Proteins were transferred to nitrocellulose sheets and probed with different IgGs from chagasic patients with megacolon or normal individuals, as previously described. ${ }^{17}$ We also tested a monospecific mouse antihuman $\mathrm{M}_{2} \mathrm{mAChR}$ IgG as a specific marker for the receptor.

\section{CYCLIC AMP ASSAY}

Human and rat distal colon smooth muscle strips were obtained as described above and incubated as previously reported. ${ }^{18}$ Normal or chagasic IgG fractions were added 15 minutes before the end of the reaction and $\mathrm{PGE}_{1}$ $\left(1 \times 10^{-6} \mathrm{M}\right)$ was added in the last five minutes as an adenylate cyclase activator. The specificity of the antibody- $\mathrm{M}_{2} \mathrm{mAChR}$ interaction was assessed by addition of $1 \times 10^{-6} \mathrm{M}$ atropine or AF-DX 116 to the incubation medium. cAMP determination was performed by competitive protein kinase binding assay, as described by Gomez and colleagues, ${ }^{19}$ using $\left[{ }^{3} \mathrm{H}\right]$ cAMP as tracer.

\section{CONTRACTILITY STUDIES}

Human and rat distal colon smooth muscle strips were obtained as described above and placed in Petri dishes filled with Krebs-Ringer bicarbonate $(\mathrm{KRB})$ solution containing $(\mathrm{mM})$ : $\mathrm{Na}^{+} 145 ; \mathrm{K}^{+}$6.02; $\mathrm{Ca}^{2+} 2.2 ; \mathrm{Mg}^{2+} 1.33 ; \mathrm{Cl}^{-} 126$; $\mathrm{HCO}_{3}{ }^{-} 25.3 ; \mathrm{SO}_{4}{ }^{2-} 1.33 ; \mathrm{HPO}_{4}{ }^{2-} 1.20$; and glucose 5.5. The strips were mounted on an organ bath containing $\mathrm{KRB}$ solution at $37^{\circ} \mathrm{C}$ gassed with $5 \% \mathrm{CO}_{2}$ in oxygen at $\mathrm{pH} 7.4 .{ }^{18}$ One end of each tissue was anchored to a stationary glass holder and the other was connected to a force displacement transducer (Stathan UC-3 Gold Cell) coupled to an ink writing oscillograph (Grass RPS 7C). A constant resting tension of $500 \mathrm{mg}$ was applied to preparations, and strips were allowed to equilibrate for 30 minutes. Each preparation was exposed to different concentrations of IgG antibodies from chagasic patients with megacolon or normal control subjects over 15 minutes. Inhibition experiments were performed by incubating tissues with $5 \times 10^{-6} \mathrm{M}$ AF-DX 116 or pertussis toxin for 30 minutes before addition of the antibodies.

\section{STATISTICAL ANALYSIS}

Prevalence values between groups were compared by the $\chi^{2}$ test. For multiple comparisons among mean values, data were first examined by analysis of variance, and differences between means were evaluated by the StudentNewman-Keuls test. All statistical significances were justified at $\alpha=0.05$.

\section{Results}

CHAGASIC IgG BINDING TO COLON mAChR The interaction between serum IgG from chagasic patients with megacolon mAChRs and colon smooth muscle membranes is shown in fig 1 . IgG from chagasic patients with megacolon (group I) but not from normal subjects (group III) inhibited specific binding of 
- Chagasic with megacolon

A Chagasic without megacolon

- Non-chagasic with megacolon

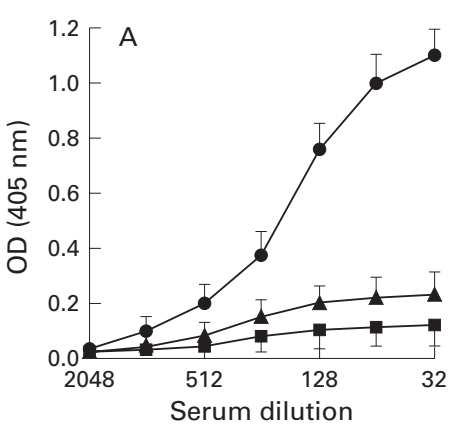

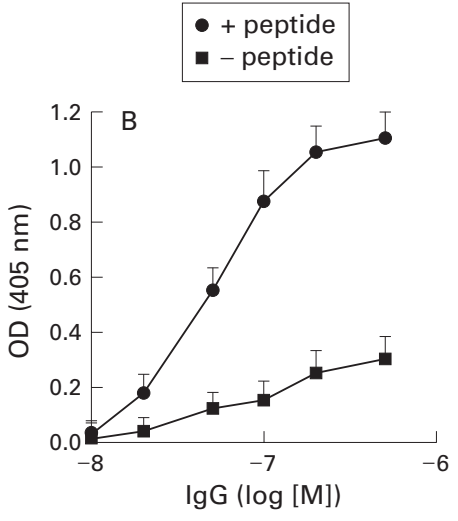

Figure 2 Immunoreactivity of anti-muscarinic acetylcholine receptor ( $m A C h R$ ) antibodies from chagasic sera against the second extracellular loop of the human $M_{2}$ $m A C h R$ tested by ELISA. Microtitre wells were coated with $1 \mu \mathrm{g}$ of $M_{2}$ peptide and an enzyme immunoassay was performed (see materials and methods). (A) Mean (SEM) optical density (OD) values, representing triplicate assays from 15 chagasic patients with megacolon, 17 chagasic patients without megacolon, and three non-chagasic patients with megacolon. (B) Mean (SEM) optical density (OD) values, representing triplicate determinations of five affinity purified antipeptide IgGs from different chagasic patients with megacolon in the presence (+) or absence (-) of $1 \times 10^{-5} \mathrm{M}$ peptide.

cholinergic radioligand $\left[{ }^{3} \mathrm{H}\right]$ NMS to rat (fig 1A) and human (fig 1B) colon membrane preparations in a concentration dependent manner.

In saturation studies and Scatchard analysis (table 1), an irreversible interaction was established. Thus when rat and human colon preparations reacted with chagasic IgG, a decrease in the number of binding sites (Bmax) without a significant change in the equilibrium dissociation constant $(\mathrm{Kd})$ was observed. IgGs from groups II, III, and IV gave negative results.

DETECTION OF SERUM AUTOANTIBODIES AGAINST HUMAN $\mathrm{M}_{2}$ mAChR

To determined the molecular interaction between autoantibodies from chagasic patients with megacolon and human $\mathrm{M}_{2} \mathrm{mAChR}$, we carried out an enzyme immunoassay using the synthetic $24 \mathrm{mer}$ peptide corresponding in amino acid sequence to the second extracellular loop of human $\mathrm{M}_{2} \mathrm{mAChR}$.

As can be seen in fig $2 \mathrm{~A}$, immunoreactivity of sera from chagasic patients with megacolon (group I) was significantly higher than in sera from chagasic patients without megacolon (group II) $(\mathrm{p}<0.0005)$ and from non-chagasic patients with megacolon (group III) $(\mathrm{p}<0.0001)$. Values for optical density in group I were always higher than 3 SDs compared with those from normal individuals (group IV).

Then, IgG fractions from chagasic patients with megacolon were subjected to affinity chromatography purification on the $\mathrm{M}_{2}$ synthetic peptide (anti- $\mathrm{M}_{2}$ peptide IgG) and their immunoreactivity against the $M_{2}$ peptide was evaluated. As shown in fig $2 \mathrm{~B}$, the anti- $\mathrm{M}_{2}$ peptide $\mathrm{IgG}$ increased optical density values in a concentration depended manner. The specificity of these anti- $\mathrm{M}_{2}$ peptide IgGs was assessed by the ability of the $M_{2}$ peptide (10-fold concentration) to inhibit the interaction.

It is important to note that when a synthetic peptide corresponding in amino acid sequence to the second extracellular loop of human $\mathrm{M}_{3}$ mAChR was used as a coating antigen for
Table 2 Immunoreactivity of circulanting $\operatorname{Ig} G$ antibodies against the second extracellular loop of the $M_{2}$ and $M_{3}$ muscarinic acetylcholine receptor ( $m A C h R$ ) tested by ELISA

\begin{tabular}{lll}
\hline \multirow{2}{*}{ Sera } & \multicolumn{2}{l}{$O D(405 \mathrm{~nm})$ synthetic peptide } \\
\cline { 2 - 3 } & $M_{2} m A C h R$ & $M_{3} m A C h R$ \\
\hline None & $0.12(0.02)$ & $0.18(0.02)$ \\
Group I & $1.17(0.1)^{\star}$ & $0.20(0.03)$ \\
Group II & $0.15(0.05)$ & $0.17(0.03)$ \\
Group III & $0.18(0.06)$ & $0.23(0.04)$ \\
Group IV (control) & $0.16(0.03)$ & $0.20(0.02)$ \\
\hline
\end{tabular}

Microtitre wells were coated with $1 \mu \mathrm{g}$ of $\mathrm{M}_{2}$ or $\mathrm{M}_{3} \mathrm{mAChR}$ peptides and enzyme immunoassay was carried out with sera from different groups.

Values are mean (SEM) of serum sample (1/32 dilution) from 13 chagasic patients with megacolon (group I), 13 chagasic patients without megacolon (group II), three non-chagasic patients with megacolon (group III), and 15 normal subjects (group IV)

OD, optical density.

*Significantly different from normal control, $\mathrm{p}<0.0001$.

ELISA, negative results were obtained with circulating IgG antibody from all groups (table 2).

To further investigate the interaction between anti- $\mathrm{M}_{2}$ peptide IgG and colon $\mathrm{M}_{2}$ mAChRs, we carried out immunobloting experiments on rat and human colon smooth muscle preparations and tested the ability of anti- $M_{2}$ peptide antibody to recognise the whole receptor. Figure 3 shows that total IgG from chagasic patients with megacolon (group I) but not IgG from normal individuals (group III) recognised the whole $\mathrm{mAChR}$ on rat and human homogenates in a similar manner to a monoclonal anti- $\mathrm{M}_{2} \mathrm{mAChR}$ IgG. As expected, anti- $\mathrm{M}_{2}$ peptide IgG also revealed bands of $\mathrm{M}_{2} \mathrm{mAChRs}$ coincident with those labelled by the monoclonal IgG.

Table 3 shows the distribution of antipeptide autoantibodies in chagasic patients with (group I) or without (group II) megacolon. It can be

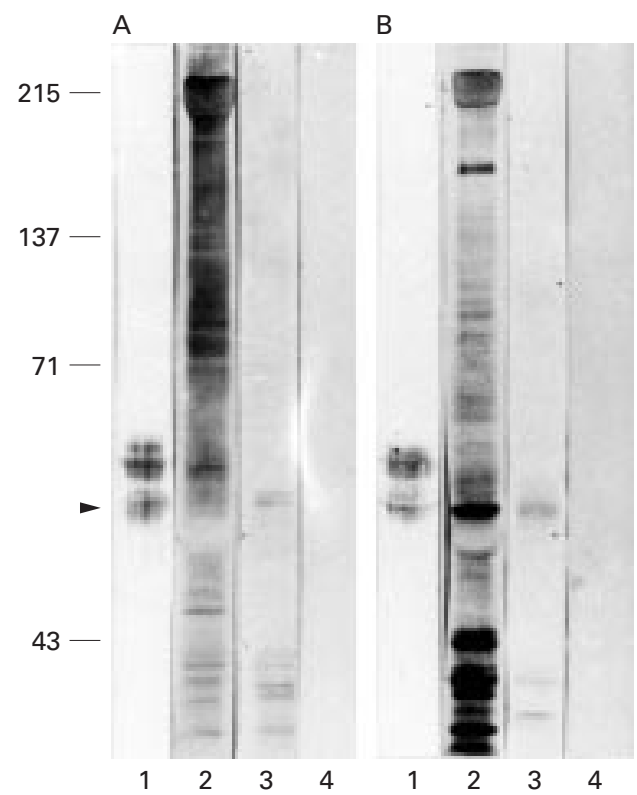

Figure 3 Immunoblotting of $M_{2}$ muscarinic acetylcholine receptor ( $m A C h R)$ on rat $(A)$ and human $(B)$ colon smooth muscle homogenates. Lane $2: \operatorname{Ig} G$ fraction from chagasic patients with megacolon; lane 3: affinity purified antipeptide IgG from chagasic patients with megacolon; lane 1: monospecific mouse antihuman $M_{2} m A C h R I g G$; and lane 4: serum IgG fraction from normal patients. 
Table 3 Age and anti- $M_{2}$ muscarinic acetylcholine receptor ( $m A C h R$ ) antibody distribution in chagasic patients with (group I) or without (group II) megacolon and in normal controls (group IV)

\begin{tabular}{|c|c|c|c|c|c|c|}
\hline \multirow{2}{*}{$\begin{array}{l}\text { Serum reactivity against } \\
M_{2} m A C h R \text { peptide }\end{array}$} & \multicolumn{2}{|c|}{ Group I } & \multicolumn{2}{|c|}{ Group II } & \multicolumn{2}{|c|}{ Group IV } \\
\hline & $n$ & Age (y) & $n$ & Age (y) & $n$ & Age (y) \\
\hline Positive & 13 & $55.9(3.1)^{\star}$ & 4 & $37.0(5.0)^{\star \star}$ & 0 & - \\
\hline Negative & 2 & $74.0(1.0)$ & 13 & $63.9(3.6)$ & 20 & $61.4(2.9)$ \\
\hline Total & 15 & $58.3(3.2)$ & 17 & $57.6(3.8)$ & 20 & $61.4(2.9)$ \\
\hline
\end{tabular}

Values are mean (SEM).

${ }^{\star} \mathrm{p}<0.05,{ }^{\star \star} \mathrm{p}<0.002$ versus seronegative patients from the same group.

Prevalence values of anti- $\mathrm{M}_{2} \mathrm{mAChR}$ antibodies between groups I and II were compared by $\chi^{2}$ test $\left(\chi^{2}=10.35, \mathrm{p}<0.001\right)$.

seen that the frequency of anti- $M_{2}$ peptide antibodies detected by ELISA was significantly higher in seropositive patients with megacolon, which accounts for the strong association between the existence of serum anti- $\mathrm{M}_{2}$ $\mathrm{mAChR}$ antibodies and the presence of megacolon in chagasic patients. Also, we can see in table 3 that there were no significant differences in patient age between the two groups. However, mean age of the four patients with positive anti- $\mathrm{M}_{2} \mathrm{mAChR}$ antibody titres from group II was significantly lower than the mean age of the 13 seropositive patients from group I. In contrast, two patients with negative anti- $\mathrm{M}_{2} \mathrm{mAChR}$ antibody titres from group I were significantly older than the mean ages of the 13 seropositive patients in the same group.

FUNCTIONAL EFFECT OF HUMAN CHAGASIC AUTOANTIBODIES

To determine if serum anti- $\mathrm{M}_{2} \mathrm{mAChRs}$ from patients with chagasic disease with megacolon exert biological actions on the distal colon smooth muscle through $\mathrm{M}_{2} \mathrm{mAChR}$ activation, we tested changes in the contractile behaviour associated with modifications in cAMP production in strips of rat and human colon exposed to such antibodies. As shown in fig 4, addition of anti- $\mathrm{M}_{2}$ peptide IgG from chagasic patients with megacolon (group I) resulted in an increase in tone of both rat and human distal colon preparations in a concentration depended manner. These effects were neutralised after preincubation of the antibodies with the peptide $\left(1 \times 10^{-5} \mathrm{M}\right)$. Moreover, the affinity purified anti- $\mathrm{M}_{2}$ peptide IgG was more potent
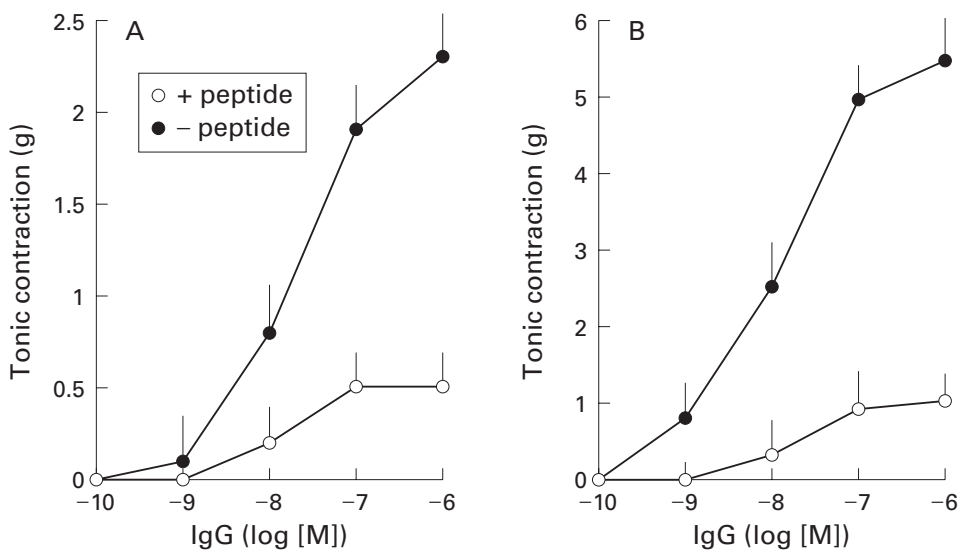

Figure 4 Concentration dependent effect of the anti- $M_{2}$ peptide Ig $G$ fraction from chagasic patients with megacolon on rat $(A)$ and human $(B)$ colon tonic contractions. Isolated distal colonic strips were incubated with affinity purified antipeptide antibodies in the presence $(+)$ or absence (-) of $1 \times 10^{-5} \mathrm{M}$ peptide and tonic contractions were recorded. Values are mean (SEM) of five antipeptide IgG fractions in each group.
Table 4 Changes in tone induced by anti- $M_{2}$ muscarinic acetylcholine receptor ( $m A C h R$ ) peptide $\operatorname{IgG}$ on colonic smooth muscle

\begin{tabular}{|c|c|c|}
\hline \multirow[b]{2}{*}{ Condition } & \multicolumn{2}{|c|}{ Tonic contraction $(g)$} \\
\hline & Rat & Human \\
\hline Chagasic IgG & $2.0(0.3)$ & $5.2(0.4)$ \\
\hline Anti- $M_{2}$ peptide IgG & $2.1(0.2)$ & $5.4(0.3)$ \\
\hline Anti-M $M_{2}$ peptide IgG+AF-DX 116 & $0.5(0.06)^{\star}$ & $0.8(0.05)^{\star}$ \\
\hline Anti-M $M_{2}$ peptide IgG+PTX & $0.7(0.08)^{\star}$ & $0.9(0.06)^{\star}$ \\
\hline Normal IgG & $0.02(0.01)$ & $0.05(0.03)$ \\
\hline
\end{tabular}

Contractile tone was measured after incubation of tissues for 15 minutes with $1 \times 10^{-6} \mathrm{M}$ anti- $\mathrm{M}_{2}$ peptide IgG or $1 \times 10^{-5} \mathrm{M}$ chagasic or normal IgG. Inhibition experiments were performed by incubating tissues with $5 \times 10^{-6} \mathrm{M}$ pertussis toxin (PTX) or AF-DX 116 over 30 minutes before addition of anti- $\mathrm{M}_{2}$ peptide IgG.

Values are mean (SEM) of anti-M $\mathrm{M}_{2}$ peptide IgG from six different chagasic patients with megacolon or normal individuals in each group.

${ }^{\star}$ Significantly different from anti-M $\mathrm{M}_{2}$ peptide IgG, $\mathrm{p}<0.0001$.

than the total IgG from the same patients. Table 4 shows that with $1 \times 10^{-6} \mathrm{M}$ of anti- $\mathrm{M}_{2}$ peptide IgG, tonic contraction was the same as that obtained with $1 \times 10^{-5} \mathrm{M}$ total IgG. Furthermore, anti- $\mathrm{M}_{2}$ peptide IgG elicited contracture was inhibited by the $\mathrm{M}_{2} \mathrm{mAChR}$ selective antagonist AF-DX 116 and by pertussis toxin. These results demonstrate that chagasic IgG elicits a cellular response by interacting with the $\mathrm{M}_{2} \mathrm{mAChR}$ coupled to a pertussis toxin sensitive $\mathrm{G}$ protein of the $\mathrm{Gi}$ family that mediates inhibition of adenylate cyclase activity. Figure 5 shows original
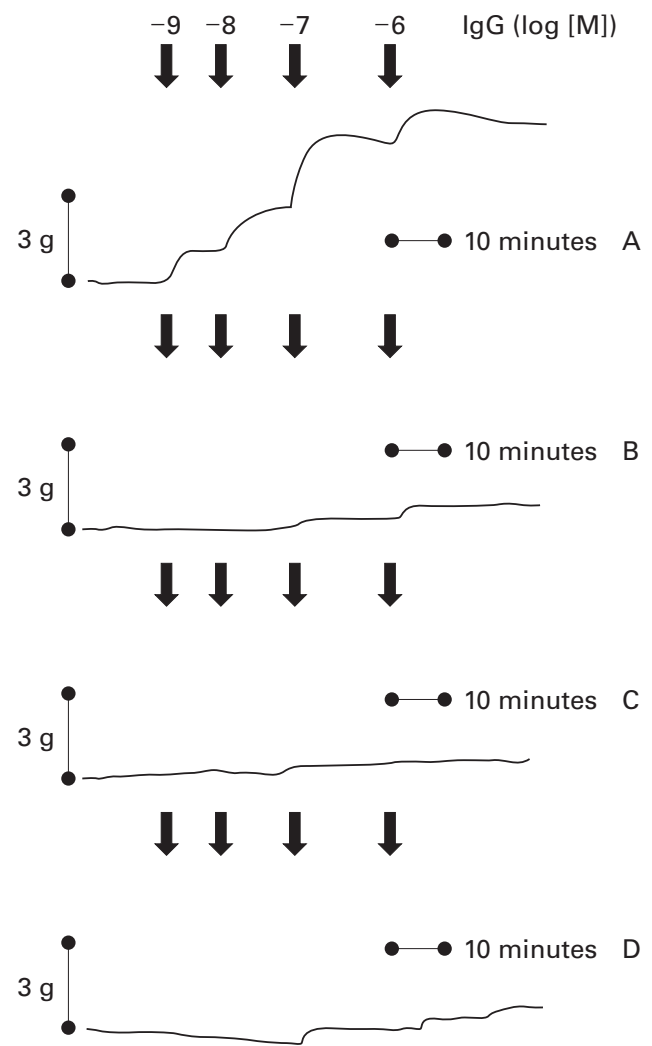

Figure 5 Original tracings showing dose dependent increases in human colon tonic contractions by anti-M peptide IgG (IgG log [M]) from chagasic patients with megacolon alone $(A)$ and after exposed tissues to $5 \times 10^{-6} \mathrm{M}$ $A F-D X 116(B), 5 \times 10^{-5} M$ synthetic $M_{2}$ peptide $(C)$, and $5 \times 10^{-6} M$ pertussis toxin (D) over 30 minutes before anti-M $M_{2}$ peptide IgG from chagasic patients with megacolon was added. 
Table 5 Effect of chagasic anti- $M_{2}$ muscarinic acetylcholine receptor ( $m A C h R$ ) antibodies on cAMP accummulation in rat and human distal colon

\begin{tabular}{|c|c|c|}
\hline \multirow[b]{2}{*}{ Additions } & \multicolumn{2}{|c|}{$c A M P$ (pmol/mg wet weight) } \\
\hline & Rat & Human \\
\hline None (basal) & $1.43(0.09)$ & $1.98(0.10)$ \\
\hline $\mathrm{PGE}_{1}$ alone & $4.32(0.35)$ & $5.60(0.34)$ \\
\hline $\mathrm{PGE}_{1}+$ chagasic IgG & $1.96(0.16)^{\star}$ & $2.35(0.15)^{\star}$ \\
\hline $\mathrm{PGE}_{1}+$ normal IgG & $4.05(0.36)$ & $5.42(0.40)$ \\
\hline $\mathrm{PGE}_{1}+$ chagasic IgG + atropine & $3.93(0.43)$ & $5.30(0.39)$ \\
\hline $\mathrm{PGE}_{1}+$ chagasic IgG $+\mathrm{M}_{2}$ peptide & $3.58(0.39)$ & $5.10(0.42)$ \\
\hline $\mathrm{PGE}_{1}+$ anti-M $\mathrm{M}_{2}$ peptide IgG & $1.87(0.22)^{\star}$ & $2.10(0.17)^{\star}$ \\
\hline $\mathrm{PGE}_{1}+$ anti-M $\mathrm{M}_{2}$ peptide IgG+AF-DX 116 & $3.85(0.41)$ & $4.95(0.45)$ \\
\hline $\mathrm{PGE}_{1}+$ anti-M $\mathrm{M}_{2}$ peptide IgG $+\mathrm{M}_{2}$ peptide & $3.94(0.40)$ & $5.12(0.40)$ \\
\hline $\mathrm{PGE}_{1}+$ anti-M $\mathrm{M}_{2}$ peptide IgG $+\mathrm{PTX}$ & $4.52(0.35)$ & $5.78(0.38)$ \\
\hline
\end{tabular}

3',5'-Cyclic monophosphate (cAMP) accumulation was measured after incubation of tissues for 15 minutes with $1 \times 10^{-5} \mathrm{M}$ total IgG or $1 \times 10^{-6} \mathrm{M}$ anti- $\mathrm{M}_{2}$ peptide $\mathrm{IgG}$ from chagasic patients with megacolon or IgG from normal subjects. Then, $1 \times 10^{-6} \mathrm{M}$ prostaglandin $\mathrm{E}_{1}\left(\mathrm{PGE}_{1}\right)$ was added five minutes before the end of the reaction. Inhibitory experiments were performed by incubating tissue for 15 minutes with $5 \times 10^{-6} \mathrm{M}$ pertussis toxin (PTX), atropine, or AF-DX 116, before IgGs were added. The $\mathrm{M}_{2}$ peptide neutralisation experiments were performed by preincubating IgG with the peptide $\left(5 \times 10^{-5} \mathrm{M}\right)$ over 30 minutes at $30^{\circ} \mathrm{C}$ prior to tissue exposition.

Values are mean (SEM) of the IgG fraction from five different chagasic megacolon patients or normal individuals.

*Significantly different from $\mathrm{PGE}_{1}$ alone, $\mathrm{p}<0.0001$.

tracings of the dose-response curve of anti- $\mathrm{M}_{2}$ peptide IgG on human distal colon preparations from patients in group I (fig 5A) and the inhibitory action of different blockers (fig 5B-D).

Consequently, we were interested in determining modifications in cAMP production by human and rat colon preparations exposed to chagasic IgG from group I. For this purpose, colon preparations were exposed to $\mathrm{PGE}_{1}$ which can activate adenylate cyclase. Table 5 shows that cAMP accumulation induced by $\mathrm{PGE}_{1}$ was significantly inhibited by both total $\operatorname{IgG}\left(1 \times 10^{-5} \mathrm{M}\right)$ and the corresponding anti- $\mathrm{M}_{2}$ peptide $\operatorname{IgG}\left(1 \times 10^{-6} \mathrm{M}\right)$ from sera of chagasic patients with megacolon; anti- $\mathrm{M}_{2}$ was more potent than total IgG. Inhibition of $\mathrm{PGE}_{1}$ induced effects triggered by chagasic IgG were neutralised by preincubation of the antibodies with the peptide and were also blocked by atropine, AF-DX 116, and pertussis toxin sensitive Gi protein. As a control, IgG from sera of group III was unaffected in the studied system.

\section{Discussion}

In the present study we have provided evidence for the presence of autoantibodies against $\mathrm{M}_{2}$ $\mathrm{mAChR}$ in chagasic patients with megacolon. These antibodies not only interacted with both human and rat colon mAChRs but also displayed muscarinic-like activity, modifying intracellular events associated with specific receptor activation. Also, a molecular interaction between chagasic antibodies from patients with megacolon and the second extracellular loop of human $\mathrm{M}_{2} \mathrm{mAChR}$ was demonstrated using a synthetic 24 mer peptide in immunobloting and enzyme immunoassays. Thus affinity purified anti- $M_{2}$ peptide $\mathrm{IgG}$, in common with monoclonal antihuman $\mathrm{M}_{2}$ $\mathrm{mAChR}$ antibody, recognised a band with a molecular weight corresponding to the colon $\mathrm{mAChR}$. The different patterns of recognition observed with total chagasic IgG corresponded with other high molecular weight proteins recognised by additional antibodies that have been reported on heart preparations. ${ }^{17}$ The specificity of the interaction with $\mathrm{M}_{2} \mathrm{mAChR}$ subtype was assessed by inhibiting immune recognition of anti- $\mathrm{M}_{2}$ peptide antibody by the $\mathrm{M}_{2}$ peptide. Also, IgG from chagasic patients with megacolon did not recognise the synthetic peptide with an amino acid sequence identical to the second extracellular loop of human $\mathrm{M}_{3} \mathrm{mAChR}$.

In distal colon strips from humans or rats, antibodies from chagasic patients with megacolon and the corresponding anti- $\mathrm{M}_{2}$ peptide IgG increased contractile tone and decreased cAMP production. These effects promoted by chagasic autoantibodies were inhibited by a selective $\mathrm{M}_{2} \mathrm{mAChR}$ antagonist, indicating the participation of $\mathrm{M}_{2} \mathrm{mAChRs}$ in the biological effect of the autoantibodies. Moreover, that the synthetic $\mathrm{M}_{2}$ peptide selectively blocked the biological action of chagasic antibodies and that the anti- $M_{2}$ peptide chagasic IgG triggered an increase in tone and decrease in cAMP confirms that the second extracellular loop of the receptor is essential to the biological action of these antibodies. ${ }^{17}$ Affinity purified anti- $\mathrm{M}_{2}$ peptide autoantibodies affected contraction, and cAMP accumulation was prevented by pertussis toxin, suggesting that the effects of these antibodies are mediated by Gi/o proteins. This result is in agreement with previous observations that showed that activation of $\mathrm{M}_{2}$ mAChR by a specific agonist causes pertussis toxin sensitive inhibition of adenylate cyclase in colonic smooth muscle. ${ }^{11}$ Such an action in smooth muscle modulates contraction by inhibiting the relaxant effect of agonist known to activate adenylate cyclase. ${ }^{20}$ However, direct colonic tonic cholinergic excitatory control by $\mathrm{M}_{2}$ mAChR subtype has been described. ${ }^{14}$

Hence our results could indicate that chagasic autoantibodies exert their biological effects through two mechanism: direct contraction and indirect contraction by prevention of the relaxant effects of cAMP generating agents. However, $\mathrm{M}_{2}$ muscarinic presynaptic autoreceptors that regulate release of acetylcholine by means of a negative feedback mechanism ${ }^{21}$ triggered by chagasic autoantibodies could not be excluded; an in vivo study is needed to demonstrated this.

Human colon smooth muscle has a greater density of $\mathrm{M}_{2}$ mAChRs than rat colon. ${ }^{22}$ Our results confirm this. The difference in $\mathrm{mAChR}$ expression could explain the higher response in the biological patterns (contractility and cAMP) triggered by chagasic autoantibodies in human compared with rat colon preparations.

The prevalence of circulating anti- $\mathrm{M}_{2}$ $\mathrm{mAChR}$ autoantibodies in chagasic patients with megacolon was significantly higher than the prevalence of such antibodies in chagasic patients without megacolon or non-chagasic patients with megacolon. It is tempting to speculate that chagasic patients without megacolon who have anti- $\mathrm{M}_{2} \mathrm{mAChR}$ autoantibodies may develop symptoms and signs of megacolon in the future. This is supported by the fact that anti- $M_{2}$ mAChR autoantibody positive patients from group II were significantly younger than patients in group I and had no more than five years of evolution. These chagasic patients without megacolon should be examined periodically to evaluate the potential 
prognostic value of this test. The presence of circulating anti- $\mathrm{M}_{2} \mathrm{mAChR}$ autoantibodies with agonist activity in chagasic patients without evidence of megacolon could be explained by the fact that during the course of the disease, peak serum concentrations of antineurotransmitter receptor antibodies may precede binding to muscarinic receptors from target tissue, as was shown in chagasic and autoimmune myocarditis. ${ }^{23} 24$

On the other hand, it is difficult to explain why some chagasic patients with megacolon showed no circulating $\mathrm{M}_{2} \mathrm{mAChR}$ autoantibodies. The fact that they were significantly older than the mean age of group I with more years of evolution (30-60 years) indicates that these patients were studied during a stage of chronic chagasic disease in which autoantibodies were fixed to tissues forming an immune complex. In fact, visceral deposits of immunoglobulins in chronic Chagas' disease have been shown. ${ }^{25}$

In conclusion, we have provided evidence that most patients with Chagas' disease with megacolon have circulating autoantibodies against $M_{2}$ mAChRs. These antibodies increase contractile tone and decrease cAMP production in human and rat distal colon through specific activation of $\mathrm{M}_{2} \mathrm{mAChR}$. We suggest that the stimulatory effect of such autoantibodies, in common with other muscarinic agonists, can rapidly activate $\mathrm{mAChR}$ and thereby trigger a biological effect. ${ }^{17} 18$ However, these agonist effects are followed by receptor desensitisation and sequestration which impairs further muscarinic receptor activation, ${ }^{26}$ giving rise to megacolon. In this way autoantibodies could contribute to rectum-sigmoid motor incoordination as well as to impairment of the internal sphincter relaxation response to rectal distension. ${ }^{25}$ In contrast, if the agonist promoted contraction effect of autoantibodies predominates, microcolon could be predicted, such as is seen in aganglionosis diseases. This finding suggests that an alternative humoral factor contributes to the pathogenesis of chronic digestive damage during Chagas' disease.

The authors thank Mrs Elvita Vannucchi and Fabiana Solari for expert technical assistance. Support was provided in the form of a grant from CONICET (PIP) and University of Buenos Aires (UBACyT).

1 WHO Expert Committee. Control of Chagas' disease. Tech Report Series 1991;811:1-10.

2 Koberle F. Chagas' disease and Chagas' syndromes: the pathology of American trypanosomiasis. Adv Parasitol 1968;6:63-73.
3 Marcondes de Rezende J, Luquetti AO. Chagasic megavisceras. In: Chagas' disease and the nervous system. Pan Americeras. In: Chagas'disease and the nervous systen
can Health Organization 1994;547:149-71.

can Health Organization 1994;547:149-71.
4 Meneghelli UG. Chagas' disease: a model of the enervation in the study of digestive tract motility. Braz $\mathcal{F}$ Med Biol Res 1985;18:255-64.

5 Padovan W, Godoy RA, Dantas RO, et al. Lower esophageal sphincter response to pentagastrin in chagasic patients with megaesophagus and megacolon. Gut 1980;21:85-90.

6 Mathias CJ. Autonomic disorders and their recognition. $N$ Engl f Med 1997;336:721-4.

7 Vieira CB, Godoy RA, Carril CF. Hypersensitivity of the large intestine to cholinergic agents in patients with Chagas' disease and megacolon. Rev Bras Gastroenterol 1964;16:41-8

8 Habr-Gama A, Raia A, Correa Newtto A. Moltility of sigmoid colon and rectum: contribution to the pathophysiology of megacolon in Chagas' disease. Dis Colon Rectum 1970;14:291-304.

9 Meneghelli UG, Godoy RA, Macedo JFS, et al. Basal motility of dilated and non dilated sigmoid colon and rectum in Chagas' disease. Arq Gastroenterol Sao Pablo 1982;19:12732 .

10 Meneghelli UG, Godoy RA, Oliveira RB, et al. Effect of pentagastrin on the motor activity of dilated and nondilated and rectum in Chagas' disease. Digestium 1983;27: $152-8$.

11 Zhang L, Buxton ILO. Muscarinic receptors in canine colonic circular smooth muscle. Signal transduction pathways. Mol Pharmacol 1991;40:952-9.

12 Galligan JJ, LePard KJ, Schneider DA, et al. Multiple mechanisms of fast excitatory synaptic transmission in the enteric nervous system. F Auton Nerv Syst 2000;81:97-103.

13 Kunze WA, Fuernes JB. The enteric nervous system and regulation of intestinal motility. Annu Rev Physiol 1999,61: $117-42$.

14 Sawyer GW, Ehlert FJ. Contractile roles of the $M_{2}$ and $M_{3}$ muscarinic receptors in the guinea pig colon. $\mathcal{F}$ Pharmacol Exp Ther 1998;284:269-77.

15 Koberle F. Megaesophagus. Gastroenterology 1958;34:4606.

16 Goin JC, Borda E, Perez Leiros C, et al. Identification of ntibodies with muscarinic cholinergic activity in human Chagas' disease. F Auton Nerv Syst 1994;47:45-52.

17 Goin JC, Perez Leiros C, Borda E, et al. Interaction of human chagasic IgG with the second extracellular loop of the human heart muscarinic acetylcholine receptor: functional and pathological implications. FASEB f 1997; 10:77-83.

18 Goin JC, Sterin-Borda L, Bilder CR, et al. Functional implications of circulating muscarinic cholinergic receptor autoantibodies in chagasic patients with achalasia. Gastroenterology 1999;117:1-9.

19 Gomez A, Martos F, Bellido I, et al. Muscarinic receptor subtypes in human and rat colon smooth muscle. Biochem Pharmacol 1992;43:2413-19.

20 Ostrom RS, Frederick JE. $M_{2}$ muscarinic receptor inhibition of agonist-induced cyclic adenosine monophosphate accumulation and relaxation in the guinea pig illeum. $f$ Pharmacol Exp Ther 1997;280:189-99.

21 Blanquet F, Abysique A, Gonella J. In vivo study of the role of muscarinic receptors in the parasympathetic control of of muscarinic receptors in the parasympathetic control of
rabbit colonic motility. F Auton Nerv Syst 1994;46:217-27.

22 Gomez A, Martos F, Bellido I, et al. Muscarinic receptor subtypes in human and rat colon smooth muscle. Biochem Pharmacol 1992;43:2413-19.

23 Perez Leiros C, Sterin-Borda L, Cossio PM, et al. Muscarinic cholinergic antibody in experimental autoimmune myocarditis regulates cardiac function. Proc Soc Exp Biol Med 1990;195:356-63.

24 Sterin-Borda L, Gorelik G, Postan M, et al. Alterations in cardiac beta adrenergic receptors in chagasic mice and their association with circulating beta adrenoceptor-related autoantibodies. Cardiovasc Res 1999;41:116-25.

25 Brener Z. Pathogenesis of Chagas' disease: review of the present theories. In: Chagas' disease and the nervous system. Pan American Health Organization 1994;32:32-52.

26 Perez Leiros C, Sterin-Borda L, Borda E, et al. Desensitization and sequestration of human M2 muscarinic acetylcholine receptors by autoantibodies from patients with Chagas' disease. F Biol Chem 1997;272:12989-93. 